\title{
Kvinder i kommunalpolitik - er grænsen nået?
}

AF ULRIK KJÆR

Selv om kvinder udgør mindre end 30 procent af kommunal politikere er en stigning $i$ kvindeandelen ikke langere en selvfolge. Hvorfor er situationen saidan? Og skal vi anlagge et pessimistisk eller et mere fortrøstningsfuldt syn på sagen?

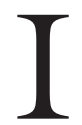

november 2001

skal der igen afholdes valg til Danmarks 275 kommunalbestyrelser. Hvis man i den anledning ønsker at gøre en form for status over kønsdimensionen i dansk kommunalpolitik, er det illustrativt at starte i Sundsøre Kommune og skrue tiden tilbage til det seneste valg i 1997. Kommunalbestyrelsen i Sundsøre var op til valget den eneste danske kommunalbestyrelse, hvori der ikke sad en eneste kvinde. Derfor besluttede fire kvinder at gøre noget ved sagen, og de opstillede deres egen liste "Kvindelist". Hvad skete der så ved valget? Først og fremmest skal det noteres, at den sorte plet blev fjernet fra Danmarkskortet, idet to kvinder blev valgt, og kommunalbestyrelsen i Sundsøre kom således til at ligne resten af landets kommunalbestyrelser derved, at begge køn igen er repræsenteret. Det skal også bemærkes, at begge de to kvinder blev valgt for Socialdemokratiet og ikke for Kvindelist.

Denne historie kunne have været inklu- 
deret for at illustrere to ting, for det forste, at kvinderne fortsætter deres indtog $\mathrm{i}$ de danske kommunalbestyrelser og for det andet, at specielle kvindelister har det svært, idet det traditionelle partisystem har koopteret kønsdimensionen. Hvor den anden pointe lader til at holde vand, gør den første det imidlertid ikke. Det der gjorde det seneste kommunalvalg i 1997 specielt var, at mens kvindeandelen som sagt steg $\mathrm{i}$ Sundsøre så faldt andelen for landet som helhed for første gang siden 1937. I de sidste 60 år er andelen langsomt men sikkert steget og nåede ved valget i 1993 op på 27.9 procent. Men ved valget i 1997 måtte man faktisk konstatere et mindre fald til 26.9 procent. $^{1}$

\section{DISKRIMINATION ELLER MÆTNINGSPUNKT?}

Når det skal vurderes, hvorfor man har set en opbremsning i den ellers kontinuerlige stigning $i$ andelen af kvindelige kommunalpolitikere og kandidater i 1990'erne, er det foreslået, at forklaringen måske ikke ligger i tiden alene, men også i selve størrelsen af kvindeandelen, som nu er kommet op i nærheden af de 30 procent (Kjær 1999). Der er således fremsat den hypotese, at stagnationen i den kommunalpolitiske kvindeandel ikke nødvendigvis skal ses som et udtryk for en opstået diskrimination mod kvinder i forbindelse med rekrutteringsprocessen. I stedet skal opbremsningen måske ses som et udtryk for, at der er opnået om ikke et ligevægtspunkt så i hvert fald et mere eller mindre momentalt mætningspunkt (Kjær 1999). Vi er måske i en tid, hvor den faktiske kvindeandel har "indhentet" vores normative ønsker til denne størrelse, og hvor potentialet for en yderligere stigning således ikke længere er til stede. Empirisk skulle dette vise sig ved, at forskellene i kvindeandelene på de enkelte lister skal blive mindre omkring det nuværende niveau. Derfor er listerne i figur 1 inddelt efter deres andel af kvindelige kandidater ved val- get i 1993, og så er der set på, hvor mange af listerne i de respektive grupper som ved det efterfølgende valg i 1997 oplevede henholdsvis en frem- og tilbagegang i kvindeandelen.

Figur 1: Andringerne i listernes andel af kvindelige kandidater mellem kommunalvalgene $i 1993$ og 1997 set i forbold til udgangsniveanet (1993). PDA. ${ }^{a}$

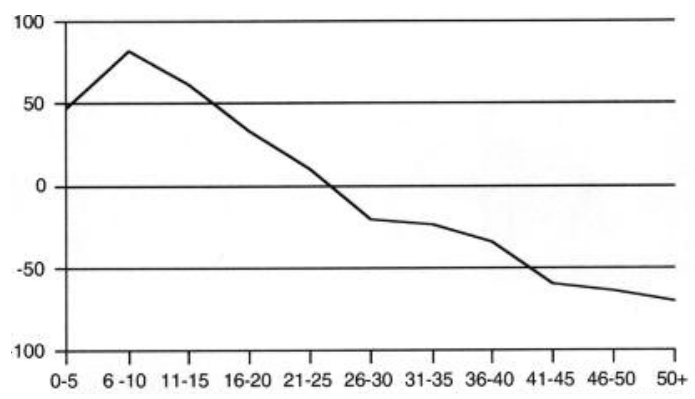

Listens andel af kvindelige kandidater $i$ udgangs-situationen (1993)

Noter: ${ }^{\mathrm{a}}$ PDI beregnet som procentdelen af lister som oplevede en fremgang minus procentdelen af lister, som oplevede en tilbagegang $i$ andelen af kvindelige kandidater.

$\mathrm{N}=1.403$ (antal lister). Kun landsdækkende partier inkluderet.

Kilde: Kjær, 2000a: 228.

Figur 1 viser, at der sker en tilnærmning. Lister med relativt mange kvinder oplever ofte en tilbagegang i kvindeandelen, mens lister med relativt få kvinder i udgangspunktet hovedsageligt kan konstatere en ditto fremgang. Endvidere ses det, at tilnærmningen sker omkring et niveau, der er lavere end 50 procent. Faktisk kan en mere præcis analyse vise, at det kritiske niveau ligger omkring 31 procent kvinder på listerne. ${ }^{2}$ Blandt de lister, der havde over dette niveau, oplevede mere end halvdelen en tilbagegang i kvindeandelen ved det seneste valg i 1997.

Men hvorfor indtræffer denne påståede mætning i givet fald? Hypotesen kunne være, at de nominerende partiorganisatio- 
ner og de udpegende vælgere kort og godt har fået kvinder nok, og stiller sig tilfredse med det nuværende niveau. Den socialdemokratiske underrepræsentation af kvinder er ikke længere så iøjnefaldende, og man kan derfor med god samvittighed rette opmærksomheden mod andre karakteristika ved kandidater og politikere. Køn er måske ikke blevet en glemt, men så i hvert fald klemt dimension i mange partiers og vælgeres bevidsthed. Skal man forholde sig empirisk til disse hypoteser, løber man ind i det problem, at der ikke eksisterer tidsseriedata, som kan belyse problemstillingerne. I stedet må det søges udnyttet, at stagnationen i 1990'erne faldt tidsmæssigt sammen med en omfattende dataindsamling omkring kommunalvalget i 1993.

Indenfor rekrutteringsteorien skelnes der ofte mellem en udbuds- og en efterspørgselsside i relation til rekrutteringsprocessen (Norris \& Lovenduski 1995, 144).Traditionelt har man søgt forklaringerne på kvindernes numeriske underrepræsentation på efterspørgselssiden, nemlig hos de politiske partier og vælgerne. Spørger man formændene for de lokale partiforeninger, så viser det sig, at der er et udbredt ønske om at få "et nogenlunde ensartet antal kandidater af begge køn". To tredjedele af formændene i en gennemført survey angiver, at dette var et vigtigt eller meget vigtigt ønske til deres kandidatlistes sammensætning (Kjær 2000, 135). Samtidig er det dog nok så vigtigt at nævne, at andre karakteristika såsom kandidaternes erhverv, alder, "kendthed" og tilknytning til geografiske dele af kommunen samlet set stod højere på ønskesedlerne rundt omkring i partiforeningerne. Mrthedshypotesen understøttes dog især af en nærmere analyse af, hvad udtrykket "et nogenlunde ensartet antal kandidater af begge køn" egentlig betyder for disse partiforeningsformænd. Formændene er nemlig også blevet spurgt om, i hvor høj grad deres ønske om stort set lige mange kvinder og mænd blev opfyldt, og disse tilkendegivelser er i figur 2 kombineret med den kvindeandel, partierne rent faktisk præsenterede på deres lister. Figur 2 viser, at opfyldelsen af ønsket om kønsmæssig ensartede lister på ingen måde lader til at fordre en fifty-fifty fordeling eller bare 4045 procent kvinder. Blandt lister, der reelt havde mellem 30 og 40 procent kvinder på deres lister og en ligelig kønsmæssig fordeling som et ønske, er det således hele ni ud af ti partiforeningsformænd, som efterfølgende erklærede sig tilfredse med dette resultat. $^{3}$

Figur 2: Andel af partiforeningsformand, som syntes at deres onske om en konsmassig afbalanceret liste blev opfyldt ved kommunalvalget $i$ 1993. opdelt efter hvor stor andel af listens kandidater, som var kvinder.

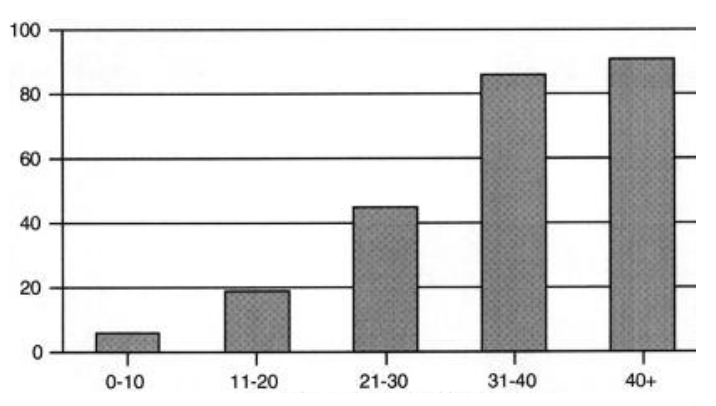

Procentdel kvindelige kandidater

Noter:

a Partiforeningsformænd som svarede, at deres ønske var opfyldt i høj grad eller nogenlunde opfyldt (den tredie svarkategori var "ikke opfyldt".

b Kun lister, hvor hensynet til et "nogenlunde ensartet antal kandidater af begge køn”, blev anset for meget vigtigt eller vigtigt er inkluderet.

$\mathrm{n}=256$. Kilde: Kjær, 2000a: 137 .

Selv om der i de enkelte partiforeninger givetvis kan forekomme såvel negativ som positiv diskrimination af kvinder $\mathrm{i}$ forbindelse med kandidatopstillingen, lader det således til, at der samlet set er tale om et billede af en mætningssituation. Ikke kun opmærksomhedsmæssigt, hvor det viser sig, at kønsdimensionen indgår i en skarp konkurrence med andre dimensioner, men også 


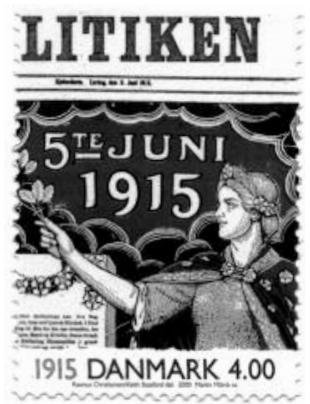

niveaumæssigt, hvor mange partiforeningsformænd lader til at have deres tilfredshedspunkt i relation til andelen af kvinder et pænt stykke under den matematiske lighed på 50 procent. Har man stort set ingen kvinder på listen, kan der være en stor interesse $\mathrm{i}$ at kæmpe aktivt for at få nogle med, om ikke andet som "listepynt" (Hellevik \& Skard 1985, 104). Men på baggrund af den gennemførte surveyundersøgelse lader der ikke for nuværende til at være nogle væsentlige ambitioner om at arbejde for at hæve andelen væsentligt over de 30 procent.

Blandt vælgerne findes der utvivlsomt dem, der diskriminerer såvel positivt som negativt mod enkelte kandidater udelukkende med udgangspunkt i disse kandidaters køn. Men igen skal det søges vurderet, om der i vælgerskaren samlet set eksisterer et potentiale for at hæve kvindeandelen op over den aktuelle. Hidtil har man anset vælgerne for at være positive overfor at få flere kvinder indvalgt i kommunalbestyrelserne, men at effekten af de personlige stemmer på kvinder afgivet med kønsdimensionen som motivation er blevet dæmpet eller måske ligefrem forhindret af partierne. Gennem partiernes prioritering af kandidaterne på listerne er kvinderne blevet holdt "nede". Dette mønster er der faktisk fundet en tendens til ved danske kommunalvalg (Kjær 1999, 154), men pointen er samtidig, at udover at tendensen ikke er særlig kraftig, så har de institutionelle arrangementer ændret sig til ugunst for de partiforeninger, der på denne vis måtte ønske at diskriminere negativt mod de kvindelige kandidater. Siden 1985 har det nemlig været muligt at opstille sideordnet, hvilket betyder, at det udelukkende er antallet af personlige stemmer, der afgør, hvem af de enkelte partiers kandidater, som ender i kommunalbestyrelserne. Ved valget i 1997 opstillede hele 72 procent af listerne på denne sideordnede facon.

Men hvordan udnytter vælgerskaren så den større indflydelse på personsammensætningen? Her viser en analyse af valget i 1993, at kvindeandelen ikke bare falder på de lister, der opstiller på partiliste, men også på de sideordnede lister, hvor vælgerne altså alene har det afgørende ord. Mens kvinderne udgjorde 27.6 procent af kandidaterne på de sideordnede lister var kvindeandelen kun 26.2 blandt de indvalgte politikere fra disse lister. Samlet set skete der et fald i kvindeandelen i forbindelse med valgfasen fra 29.6 procent (blandt kandidater) til 27.8 procent (blandt valgte). På trods af at man rensede for den effekt partiernes prioritering havde på de partilisteopstillede lister, ville der stadig være tale om et fald som følge af vælgernes indtog på banen, idet andelen i dette tilfælde ville have været blevet 28.8 procent (Kjær 2000, 168). Der er tilstrækkeligt med kvindelige kandidater på listerne til at fylde kommunalbestyrelserne udelukkende med kvinder, men det lader til, at vælgerskaren som helhed ikke ønsker at diskriminere positivt overfor kvinderne. Omvendt lader det altså heller ikke til, at vælgerskaren som helhed diskriminerer negativt overfor kvinderne i noget væsentligt omfang og samlet set er konklusionen derfor som fremhævet andetsteds: "When women run, women win - as often as men do" (Seltzer et al. 1997, 79).

Selv om resultaterne fra efterspørgselssiden således indikerer, at partierne og vælgerne som helheder betragtet har fået kvinder "nok" i den kommunalpolitiske arena, fører dette ikke til, at man i relation til det statiske niveau af kvinder i kommunalbestyrelserne automatisk kan støtte sig til de me- 
re udbudsorienterede forklaringer. Det kan også have den mere "naturlige" forklaring, at de allerede indvalgte har en fordel af deres anciennitet og derfor meget ofte genvælges, og at det således er udskiftningens træghed, der i øjeblikket hindrer en mere ligelig kønsmæssig fordeling (Bullock \& MacManus 1991, 80). En sådan forsinkelseshypotese (Raaum 1995, 30) finder imidlertid ingen støtte $\mathrm{i}$ den danske empiri (Kjær 1999, 163). Selvom det er en slags residualforklaring, må der derfor nok omend forsigtigt peges på udbudssiden, når opgaven er at finde svaret på, hvorfor andelen af kvindelige kommunalpolitikere ikke er identisk med mændenes ditto. Der er færre kvinder i kommunalpolitik end mænd, fordi kvinder ikke i lige så høj grad som mænd har tid og lyst til at søge at opnå et kommunalpolitisk mandat. Denne hypotese understøttes også af tabel 1 , hvor partiforeningsformændene er blevet bedt om at tage stilling til en række ofte hørte forklaringer på kvindernes for øjeblikkelige numeriske underlegenhed i de danske kommunalbestyrelser.

Det kan ses i tabel 1, hvor påstandene er rangeret efter, hvor enige partiforeningsformændene er i dem, at de fire udbudsforklaringer i denne "konkurrence" kommer ind på de fire første pladser, mens de fire efterspørgselsforklaringer kommer ind på de fire nederste. Nøjagtig samme rangordning er i øvigt fremkommet i samtidige undersøgelser gennemført blandt kandidater og afgående kommunalpolitikere $(\mathrm{n}=192)$ (Kjær 2000, 224). Man kunne naturligvis frygte, at resultatet fremkommer fordi, der er en overvægt af mandlige respondenter, således er 83 procent af partiforeningsformændene mænd. Det viser sig imidlertid, at der ikke er væsentlig forskel på den måde, henholdsvis mandlige og kvindelige formænd begrunder de relativt fă kvinder i kommunalpolitik på (Kjær 2000, 224). Samtidig med at tabel 1 altså således peger på, at det især er kvinderne selv, der holder sig væk fra kommunalpolitik, fortæller den jo også no- get om årsagerne til denne passivitet. Der peges på ret traditionelle begrundelser som større ansvarsfølelse overfor og arbejdsbyrde i relation til husførelse og yngelpleje samt mindre interesse for politiske spørgsmål.

Det er naturligvis svært at vide præcis, hvor meget der skal lægges i, at kvindeandelen er faldet ved et enkelt valg, men hvis det viser sig, at man i hvert fald momentalt har "mødt muren", så lader det til, at forklaringen først og fremmest skal søges i at den generelle ligestilling kønnene imellem ikke var fuldstændig i 90'erne. Mange har i perioden med kontinuerlig stigning $i$ andelen af kvinder i valgte forsamlinger stolet fuldt og fast på, at tingene nu var ved at rette sig ind, og at vi tilbagelænet kunne følge kvindeandelens vej mod halvdelen (Darcy et al. 1994, 49). Men ovenstående analyser har vist, at udviklingen i de nærmeste år måske ikke er helt så på forhånd given.

Omvendt skal det heller ikke hævdes, at udviklingen for altid er stagneret. Normer om den passende kvindeandel må antages at være en ret dynamisk størrelse, og derfor skal mæthedshypotesen ikke ses som et forsøg på at spå om, hvad der vil ske med kvindeandelen i fremtiden. I stedet er den "kun" et forsøg på at forklare den øjeblikkelige stagnation. Den empiriske støtte, der er fundet til hypotesen, er givet det beskedne datamateriale kun sporadisk, og under alle omstændigheder er det jo ikke god forskningsmæssig latin, at teste hypoteser på samme data, som har været anvendt til at opstille hypoteserne. Det virker derfor naturligt at inddrage vores skandinaviske na-

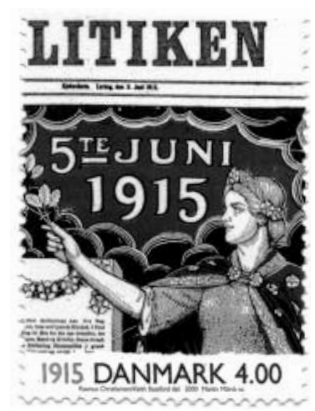


TABEL 1: PARTIFORENINGSFORMÆNDS FORKLARINGER PÅ, HVORFOR DER ER SÅ RELATIVT FÅ KVINDER MED I KOMMUNALPOLITIK. PROCENT.

Kvinderne sætter ofte hensynet til familien over det politiske

Mænd er mindre tilbageholdende end kvinder, når der opstilles

Kvinder er ikke så interesserede i politik som mænd er

Kvinder mangler i højere grad end mænd selvtillid

Partierne giver ikke kvinder gode muligheder for at blive indvalgt

Kvinder er ikke så gode stemmeslugere som mænd

Kvinder mangler oftere end mænd erfaring og uddannelse

Kvinder egner sig ikke så godt til politisk arbejde som mænd

$\begin{array}{cccc}\text { Enig } & \text { Nentral } & \text { Uenig } & \text { Opinionsbalancea } \\ 73 & 13 & 14 & 59 \\ 66 & 19 & 15 & 51 \\ 48 & 12 & 40 & 8 \\ 34 & 15 & 51 & -17 \\ 17 & 15 & 68 & -51 \\ 15 & 16 & 69 & -54 \\ 14 & 17 & 69 & -55 \\ 7 & 8 & 85 & -78\end{array}$

Note: a Beregnet som andel enige minus andel uenige. $\mathrm{n}=412$. Kilde: Kjær, 2000a: 224.

bolande, da de udmærker sig ved ligesom Danmark at have en relativ høj andel kvindelige kommunalpolitikere, og dermed grobund for samme mætning, som den vi har oplevet i Danmark.

Det viser sig, at der ikke er tegn på nogen mætningstilstand i vore skandinaviske nabolande. Ved de seneste kommunalvalg opnåedes i Sverige en kvindeandel på 41.6 procent (1998), i Island 28.2 procent (1998), i Norge 34.3 procent (1999) og i Finland 34.4 procent (2000), og det var i alle fire lande ensbetydende med, at der blev sat ny rekord, hvad angår andel af kvindelige kommunalpolitikere. ${ }^{4}$ Faktisk er det inden for de seneste 20 år kun ved valget i Norge i 1991, at man finder en nedgang. Umiddelbart taler dette imod mætningshypotesen, men måske også kun umiddelbart. Selvom landene ligner hinanden for så vidt angår en relativ høj andel af kvinder i kommunalbestyrelserne, er hovedkonklusionen på en af de seneste komparative analyser af kønspolitiske spørgsmål $i$ relation til disse lande, at de faktisk er mere forskellige end normalt antaget (Borchorst et al. 1999). Især påpegningen af, at kønsspørgsmålet spiller en relativt mindre rolle internt $\mathrm{i}$ de politiske partier i Danmark, må siges at være interessant (Borchorst et al. 1999, 262). De danske partier har, som der skal vendes tilbage til, eksempelvis et mere lunkent forhold til kønsmæssig kvotering (Christensen, 1999).

\section{Pessimisme ELLER}

\section{FORTRØSTNINGSFULDHED?}

Hvordan skal vi så mere normativt forholde os til tingenes tilstand? Først og fremmest er det nødvendigt at reflektere over, hvorvidt en kvindeandel i kommunalbestyrelser- 
ne i dag på 27 procent er problematisk eller ej. Og i fald man måtte bedømme denne størrelse som problematisk videre, om den sete opbremsning skal vurderes med pessimistiske eller mere fortrøstningsfulde briller? En kvindeandel på 27 procent vurderes utvivlsomt umiddelbart som værende i modstrid med manges ønsker om en vis form for demografisk afspejling kommunalbestyrelser og vælgerkorps imellem. Omvendt kommer et sådant krav om sociodemografisk representativitet ofte som en rygmarvsreaktion. På et empirisk plan kan man godt tilføje en sådan refleksreaktion nogle ridser i lakken i relation til den kommunalpolitiske kontekst. Eksempelvis er det påvist, at kvindelige kommunalpolitikeres udgiftspræferencer ikke afviger væsentligt fra mændenes i relation til kommunale serviceområder (Kjær 2000, 290). Køn betyder ikke noget for udgiftspræferencerne, det er de politiske partier som er omdrejningspunktet her. To socialdemokratiske kommunalpolitikere, hvoraf den ene er en kvinde, har mere til fælles end to kvindelige kommunalpolitikere, hvoraf den ene er socialdemokrat. Kritikken mod den ellers ofte forekommende sociodemografiske determinisme findes også i litteraturen, hvor angrebet mod for udstrakte tendenser til essentialisme (Mansbridge 1996, 9), netop ofte føres med de politiske partiers traditionelle negligering som argument (Norris \& Lovenduski 1995, 210; Phillips 1995, 77).

Men også på det teoretiske plan kan der stilles spørgsmålstegn ved den blinde forfølgelse af matematisk ligelig repræsentation. Eksempelvis tenderer et krav om en sådan jo mod at anse politikerne for at være døve og egoistiske. Implicit indeholder et krav om afspejling jo en opfattelse af, at politikerne ikke i tilstrækkeligt omfang er i stand til at få input fra andre. Ligeledes må der ligge en implicit antagelse om, at politikerne kun ønsker at varetage interesser for dem selv og deres egne. Og spørgsmålet er jo netop, om politikerne ikke besidder kapaciteten til at være lyttende og indtænke andres interesser i deres beslutninger (Phillips 1995, 53). På det teoretiske plan lægges der også ofte vægt på argumentet om den nødvendige eller kritiske masse (eks. Dahlerup 1988). Det nytter ikke noget, at der er en enkelt eller to kvinder i en kommunalbestyrelse, for så længe de er i markant undertal, bliver de enten overhørt eller "tvunget" til at "tude blandt ulve". Nu kunne man jo også hævde, at "if representing means presenting a point of view, one spokesman is as good as ten" (Pitkin 1967, 84), og derfor bør den traditionelle minimum kritiske masse måske suppleres med ideen om en maksimum kritisk masse (Kjær 2000, 303). Ligesom man indenfor en minimum formulering kan forestille sig, at værdien af den enkelte kvindelige repræsentant, i fald hun er stort set alene, er begrænset, kan man måske også forestille sig, at den marginale værdi af en ekstra kvindelig repræsentant, i fald hun udbygger en allerede betragtelig andel kvinder, kun vil være begrænset. Men der eksisterer også argumenter for, at en kvindeandel på eksempelvis 27 procent kan bedømmes som værende for lav. Det vigtigste af disse er for nuværende ikke empirisk belyst i en dansk kommunal kontekst, men teoretisk tager det afsæt i, at det måske i højere grad end i forbindelse med den egentlige præferenceaggregering er i de forudgående problemog løsningsformulerende faser, at køn har en betydning. Ved at have flere kvinder med, får man "access to a greater diversity of ideas and experiences that fuel definition of problems and the creations of solutions" (Thomas 1994, 147). En stor del af den revitalisering, der er set af kravet om flere kvinders tilstedeværelse i politiske organer, er netop funderet i politikkens sådanne mere deliberative elementer (Phillips 1995; Mansbridge 1996). Tydeligst får dette sit udtryk i Iris Marion Young's idé om et "social perspective" (Young 1997).

"Representing an interest or an opinion, I suggest, usually entails promoting certain specific outcomes in the decision-making 


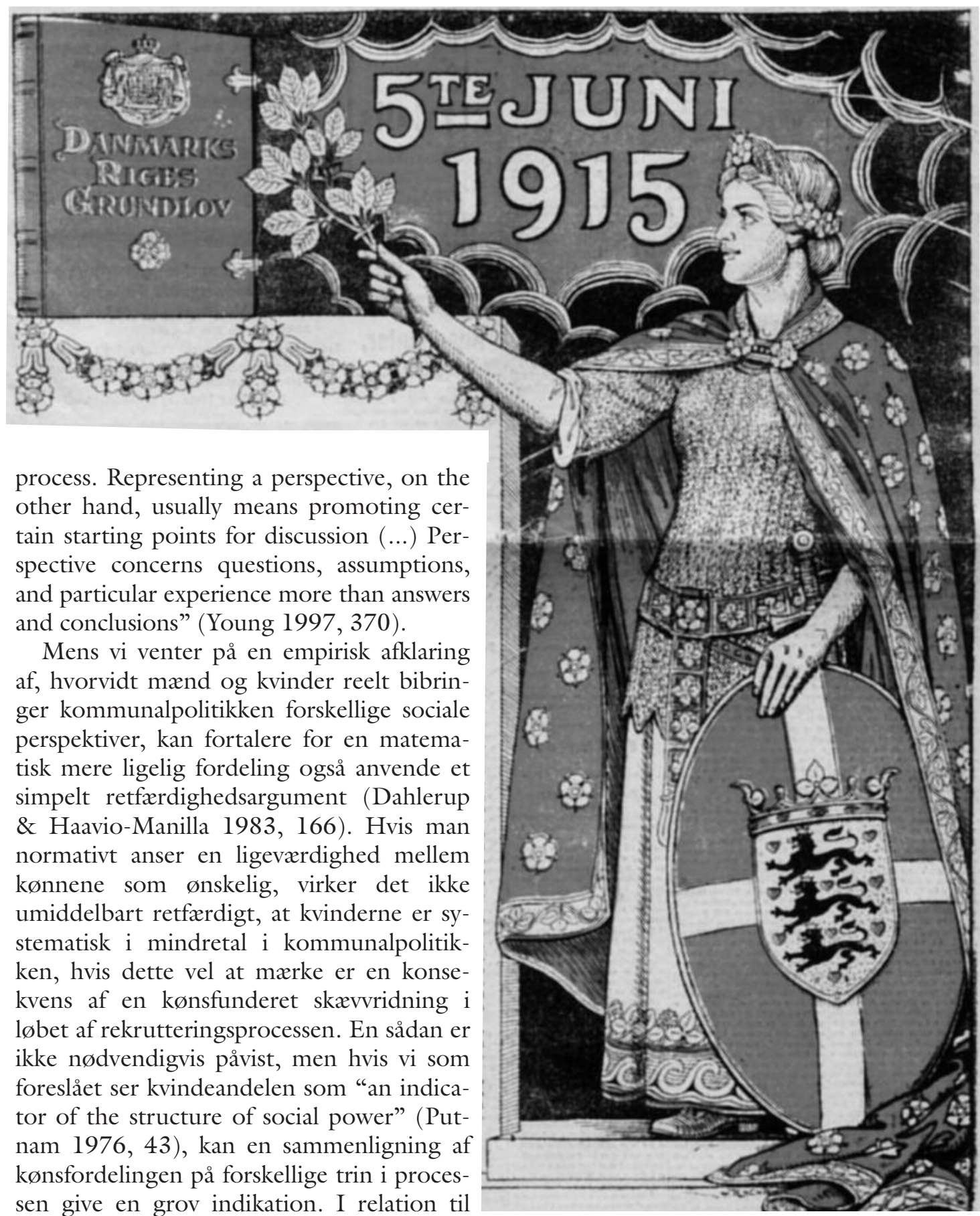
dansk kommunalpolitik er det demonstreret, at jo tættere vi kommer på magtens tinder, desto koldere bliver der for kvinderne - kvindeandelen er 51 blandt vælgere, 29 blandt kandidater, 27 blandt kommunalpolitikere, 22 blandt udvalgsformænd og 9 blandt borgmestre (Kjær 2000, 218). Så

her lader der til at være en parallel mellem dansk og norsk kommunalpolitik, hvor det er sagt, at "jo mere makt, desto færre kvinner" (Hellevik \& Skard 1985, 31). ${ }^{5}$

I relation til den nuværende kvindeandel kan der samles op på den måde, at har man 
et ønske om ligeværdighed mellem kønnene som normativ præmis, må den nuværende situation nok bedømmes med afmålt pessimisme. Pessimistisk fordi den numeriske underlegenhed er ret systematisk, men dog afmålt fordi køn ikke nødvendigvis hverken forklarer eller betyder alt på den kommunalpolitiske scene. Men hvordan skal så stagnationen bedømmes? Af gode grunde er dette spørgsmål vanskeligt at besvare, for det vi reelt er interesseret i, er jo hvad fremtiden vil bringe. Eller anderledes formuleret om opbremsningen i 1990'erne var en anomali eller en indvarsling af, hvilket leje kvindeandelen vil lægge sig fat i. Hvilke af de to scenarier, som vil realiseres, kan vi ikke for nuværende give et kvalificeret bud på. Selvom der er argumenteret for, at der er indtrådt en form for mætning, ved vi nemlig ikke noget om, hvad det er folk er mætte af - om det er af kvinder eller af kønsdimensionen. Det kan være, at mætningen går på kvinder som sådan, ved at man generelt finder en kvindeandel i underkanten af de 30 procent acceptabel. I dette tilfælde må situationen bedømmes pessimistisk, hvis man har som præmis, at kvindeandelen gerne skulle bevæge sig nærmere en matematisk ligelighed. Men mætningen kan også gå på kønsdimensionen forstået på den måde, at stagnationen ikke er udtryk for, at man nødvendigvis har fàet kvinder nok, men i stedet at man har fàet nok af kønsdimensionen, og at køn er blevet en klemt variabel i relation til den kommunalpolitiske rekrutteringsdiskussion. Er dette tilfældet, kan udviklingen også tolkes pessimistisk, idet ændring sandsynligvis kræver opmærksomhed.

Men man kan faktisk også anlægge en mere fortrøstningsfuld tolkning, fordi det kan hævdes både naturligt og ønskeligt, at kønsdimensionen på et tidspunkt træder en anelse i baggrunden. Naturligt fordi kønsdimensionen bliver vanskeligere at bruge som platform, i takt med at flere og flere kvinder indvælges. I en situation med kun ganske få kvinder i kommunalpolitikken kan disse sikkert med succes føre valgkamp og drive politik med udgangspunkt i deres køn alene, men det vanskeliggøres formodentlig, når kvindeandelen stiger. I takt med at flere kvinder indvælges, vil disse kvinder også på alle andre områder end deres køn tendere mod at blive mere heterogene (Dahl 1961, 34) og derfor vil forestillingen om en særlig "kvindelig" kommunalpolitikertype også få det vanskeligere. En opløsning af kønsdimensionen er vel i dette tilfælde også ønskelig. Det kunne hævdes, at reel ligeværdighed først opnås i det tilfælde, hvor køn opløses som dimension i relation til rekrutteringsdiskussionen, og politikerne vælges uafhængigt og ikke afhængigt af deres køn. Sundsøre-eksemplet som indledte denne artikel kunne for så vidt siges at understøtte denne sidste forklaring. En mere overordnet konklusion på udviklingen i kvindeandelen vil imidlertid ikke blive fortrøstningsfuld, men snarere igen afmålt pessimistisk. Der er grund til at afmåle pessimismen, for kønsdimensionen skal nok i en eller anden forstand trænges i baggrunden for, at i hvert fald det her opstillede billede af ligeværdighed kan opnås. Men omvendt lader det til, at denne fortrængning af kønsdimensionen i så fald er kommet "for tidligt".

\section{VALGET 2001 - UD AF KLEMTHEDEN?}

Ved det seneste kommunalvalg i 1997 faldt andelen af kvindelige kommunalpolitikere som sagt for første gang i 60 år. Vi ved ikke med sikkerhed, om dette skyldes, at "grænsen er nået", eller om der bare er tale om et mindre intermezzo i den fortsatte historie om den stigende kvindeandel. Ikke mindst derfor bliver det selvfølgelig også spændende at følge udviklingen i kvindeandelen, når det næste kommunalvalg løber af stabelen til efteråret. Hvis kønsdimensionen er klemt fordi, der er flere sociodemografisk underrepræsenterede grupper, som konkurrerer om opmærksomheden, kan kønsdimensionen umiddelbart godt frygtes 
at få det svært. Man kunne godt forestille sig, at især spørgsmålet om antallet af kandidater med en anden etnisk baggrund end dansk kunne gå hen og tiltrække sig en vis opmærksomhed, ligesom diskussionen af de relativt få privat ansatte kommunalbestyrelsesmedlemmer traditionelt er en alvorlig konkurrent. Men spørgsmålet er selvfølgelig også, om man i det hele taget kan gøre noget aktivt for at påvirke tingenes gang? Umiddelbart må svaret være negativt. I 1995 gennemførtes en lovgivning, der for at tiltrække flere kvinder til kommunalpolitik indførte et såkaldt "babysittertillæg", hvorefter alle kommunalpolitikere med børn i husstanden under 10 år fik et ekstra tillæg på $10.000 \mathrm{kr}$. Ideen var, at dette skulle kunne tiltrække relativt flere kvinder (Indenrigsministeriet 1994, 85). Umiddelbart er det dog vanskeligt at se, at et beskedent (og fuldt skattepligtigt) beløb skulle kunne påvirke folk, der ellers prioriterer familie frem for politik, og det er vel på ingen måde en selvfølge, at flere mødre end fædre vil bytte tiden med deres børn ud med en økonomisk kompensation.

Kvoteordninger har også været overvejet og $\mathrm{i}$ to partier endda gennemført i vejledende udgaver, nemlig i Socialdemokratiet og SF, som indførte dem i 1988 (Christensen 1999, 76). Begge steder er ordningerne imidlertid ophrvet igen (i 1996 og 1990 respektivt), så det lader ikke umiddelbart til at være en farbar vej i Danmark og da i hvert fald ikke i relation til valget til november. I øvrigt kan det i den forbindelse nævnes, at i det ene af de tilfælde, hvor man havde kvoteordningen i et kommunalt valgår, nemlig for Socialdemokratiets vedkommende i 1993, var det kun 26 procent af listerne, der levede op til målsætningen om mindst 40 procent kvindelige kandidater (Kjær 2000, 313). I relation til det forestående valg kan man nok heller ikke nå væsentligt at påvirke de mere overordnede ligestillingsforhold, der gør sig gxldende i samfundet, og som i følge ovenstående indeholder en stor del af forklaringen på, hvorfor relativt fă kvinder selv søger en kommunalpolitisk karriere. Skulle man således have et ønske om, at kvindeandelen i de danske kommunalbestyrelser bliver hævet i forbindelse med efterårets kommunalvalg, er der altså ikke meget, man på dette korte sigt kan gøre. Der er imidlertid et af de klassiske instrumenter $\mathrm{i}$ forsøget på at ændre en sådan kvindeandel tilbage, nemlig det fokus og den indirekte appel til relevante aktører, der kan opnås gennem "indsamling og formidling af facts og tal vedrørende kvinders deltagelse i beslutningsprocessen" (Leijenaar 1997, 31).

En måde at hjælpe kønsdimensionen ud af klemtheden på kan være ved at sætte fokus på, hvordan det ser ud derude i landets 275 kommunalbestyrelser. $\mathrm{Og}$ en påpegning af det ellers helt oversete faktum, nemlig at kvindeandelen ved det seneste valg faldt for første gang siden 1937, må siges at være et bidrag hertil. Hvordan potentielle kandidater, lokale partiforeninger, og vælgerne så reagerer på denne information, må være op til dem selv. Og kun tiden vil kunne vise os resultaterne af deres overvejelser.

\section{NOTER}

1. Blandt kandidater var faldet fra 29.6 til 28.6 procent, og her startede faldet allerede et valg tidligere, idet kvindeandelen ved valget i 1989 var 30.9 procent (Kjar 2000, 49).

2. Den kritiske værdi fremkommer som skæringen med X-aksen, hvis man indlægger en regressionslinie på baggrund af en analyse uden gruppering af de initiale kvindeandele (Kjær 2000, 229). Der er forskel på de enkelte partiers "mætningspunkt", men ikke på at de alle udviser en tilnærmelsestendens.

3. Igen kan en kritisk værdi bestemmes, og igen bliver denne 31 procent. Er andelen lavere end denne værdi, synes flertallet af partiforeningsformændene ikke, at deres ønske blev opfyldt - er den højere, anser flertallet derimod ønsket som opfyldt (Kjær 2000, 138).

4. Kilde: De respektive nationale statistiske bureauer. 5. Mere generelt tales der om "the law of increasing disproportion” (Putnam 1976, 33). 


\section{LITTERATUR}

- Bullock, Charles S. III \& Susan MacManus (1991): "Municipal Electoral Structure and the Election of Councilwomen", in Journal of Politics 53: 75-89.

- Borchorst, Anette; Ann-Dorte Christensen \& Nina C. Raaum (1999): "Ligestillede demokratier? Opsamling og perspektivering", in Christina Bergqvist et al. (red.) Likestilte demokratier? Universitetsforlaget, Oslo.

- Christensen, Ann-Dorte (1999): "Kvinder i de politiske partier", in Christina Bergqvist et al. (red.) Likestilte demokratier? Universitetsforlaget, Oslo.

- Dahl, Robert A. (1961): Who Governs? - Democracy and Power in an American City. Yale University Press, New Haven.

- Dahlerup, Drude \& Elina Haavio-Manilla (1983): "Summary", in Elina Haavio-Mannila et al. (eds.) Unfinished Democracy Pergamon Press, Oxford.

- Dahlerup, Drude (1988): "From a Small to a Large Minority: Women in Scandinavian Politics", in Scandinavian Political Studies 11: 275-98.

- Darcy, R., Susan Welch \& Janet Clark (1994):

Women, Elections \& Representation. 2.ed. University of Nebraska Press, Lincoln.

- Hellevik, Ottar \& Torild Skard (1985): Norske kommunestyrer - plass for kvinner?. Universitetsforlaget, Oslo.

- Indenrigsministeriet (1994): Kommunalpolitikernes arbejdsvilkår. Betenkning $n r$. 1271. Statens Information, København.

. Kjær, Ulrik (1999): "Saturation Without Parity:

The Stagnating Number of Female Councillors in Denmark", in Erik Beukel, Kurt Klaudi Klausen \& Poul Erik Mouritzen (eds.) Elites, Parties and Democracy - Festschrift for Professor Mogens N. Pedersen Odense University Press, Odense.

- Kjær, Ulrik (2000): Kommunalbestyrelsernes sammensatning - rekruttering og reprasentation $i$ dansk kommunalpolitik. Odense Universitetsforlag, Odense.

- Leijenaar, Monique (1997): Hvordan skabes der lige representation af kvinder og mand $i$ den politiske beslutningsproces. Kontoret for De Europæiske Fællesskabers Officielle Publikationer, Luxembourg.

- Mansbridge, Jane (1996): In Defense of 'Descriptive' Representation. Paper presented at American Politcal Science Association's Annual Meeting, San Francisco, 29. august-1. september.

- Norris, Pippa \& Lovenduski, Joni (1995): Political Recruitment: Gender, Race and Class in the British Parliament Cambridge University Press, Cambridge.
- Phillips, Anne (1995): The Politics of Presence:

Democracy and Group Representation. Oxford University Press, Oxford.

- Pitkin, Hanna Fenichel (1967): The Concept of Representation. University of California Press, Berkeley.

- Putnam, Robert D. (1976): The Comparative Study of Political Elites. Prentice Hall, Englewood Cliffs.

- Raaum, Nina (1995): "Women in Local Democracy", in Lauri Karvonen \& Per Selle (eds.) Women in Nordic Politics: Closing the Gap Darthmouth, Aldershot.

- Seltzer, Richard A., Jody Newman \& Melissa Voorhees Leighton (1997): Sex as a Political Variable - Women as Candidates \& Voters in U.S. Elections. Lynne Rienner Publishers, Boulder.

- Thomas, Sue (1994): How Women Legislate. Oxford University Press, New York.

- Young, Iris Marion (1997): "Deferring Group Representation", in Ian Shapiro \& Will Kymlicka (eds.) Nomos 39: Ethnicity and Group Rights New York University Press, New York.

\section{SUMMARY}

This article starts out by pointing to the rather disregarded fact that at the latest local election in 1997, the percentage of female councillors in Danish local governments decreased. This was the first decline since 1937 and in the discussion of this change a saturation hypothesis is put forward. Studying the evidence, it seems that there is no longer a potential for raising the share of female councillors, neither in the nominating organizations, i.e. the political parties, in the electorate, nor among potential female candidates. The consequences of this new situation are discussed within different normative frameworks leading to the conclusion that to some extent we ought to be concerned. It is difficult to suggest any short run initiatives which could be effective for the up-coming election in November, so we have to be content with the strategy of "pointing to the facts", a strategy this article aims to be a part of.

Ulrik Kjær, ph.d., adjunkt ved Institut for Statskundskab, Syddansk Universitet, Odense. 